Бакутін Є.I. Аналіз свропейського та вітчизняного досвіду щодо здійснення правозастосовної діяльності поліції.

У статті висвітлено досвід європейських країн, де багато зроблено для перетворення поліції на ефективний державний інститут, що користується довірою та повагою громадян. Розглянуто основні організаційно-правові засади діяльності поліції одного із найдавніших та невід'ємних компонентів світової цивілізації, концептуальне обгрунтування надійного захисту особи, суспільства та держави від злочинних посягань, забезпечення правопорядку, публічної безпеки.

Ключові слова: законність в діяльності поліції, технічні засоби, загальноєвропейські стандарти функції поліції.

Резюме

Бакутин Е.И. Анализ европейского и отечественного опыта по осуществлению правоприменительной деятельности полиции.

В статье отражен опыт европейских стран, где много сделано для преобразования полиции в эффективный государственный институт, пользующийся доверием и уважением граждан. Рассмотрены основные организационно-правовые основы деятельности полиции - одного из древнейших и неотъемлемых компонентов мировой цивилизации, концептуальное обоснование надежной защиты граждан, общества и государства от преступных посягательств, обеспечение правопорядка, общественной безопасности. полиции

Ключевые слова: законность в деятельности полиции, технические средства, общеевропейские стандарты функции

Summary

Yevhen Bakutin. Analysis of European and national experience performance of police enforcement activities.

The article reflects the experience of European countries, where much has been done to transform the police into an effective state institution, which enjoys the trust and respect of citizens. The basic organizational and legal foundations of the police - one of the oldest and inalienable components of world civilization, the conceptual justification of the reliable protection of individuals, society and the state from criminal attacks, the rule of law, public safety are considered.

Formulating the purpose of the article. The use of technical means of fixing offenses is one of the essential elements of a highly developed society. At the same time, Ukraine is actively pursuing its foreign policy towards accession to the European Union. That is why the integration intentions of our state necessitate the systematic improvement of the use of technical means of fixing offenses. Resolving objections and conflicts requires the proper regulation of the procedure for bringing the offender to justice, which, in turn, requires comprehensive scientific studies of these problems.

Technological advances have led to new challenges for human rights, as legal regulation tends to regulate existing legal relationships and does not account for the emergence of new forms. A striking example of this is the geometric progression of the use of technical means of fixing offenses by the police in compliance with public order.

According to the analysis of the law enforcement practice of the use of technical means, quite often leads to strong objections between citizens and representatives of authorized state bodies, which need their resolution and resolution. This is especially the case for the use of technical means of fixing offenses for the purpose of counteracting offenses, and also when using these technical means as evidence.

Police activity is one of the foundations for the promotion and development of pan-European values. However, in order for it to be effective, it is essential that the police respect human rights, the rule of law and the principles of democracy - otherwise these panEuropean values will be threatened.

Key words: legality of the police, technical means, pan-European standards for police functions.

DOI: 10.36695/2219-5521.1.2020.66

УДК 343.851

\title{
О.В. КРУШНІЦЬКА
}

Оксана Володимирівна Крушніцька, аспірант Чернівецького національного університету імені Юрія Федьковича*

ORCID: 0000-0003-1693-9867

\section{ОКРЕМІ ПРОБЛЕМИ НАДАННЯ БЕЗОПЛАТНОЇ ПРАВОВОЇ ДОПОМОГИ У КРИМІНАЛЬНОМУ ПРОВАДЖЕННІ}

Постановка проблеми. Створення права людини та громадянина на безоплатну правову допомогу в кримінальному провадженні породжує зобов'язання держави надавати юридичну допомогу, що здійснюється безпосередньо державними органами та посадовими особами, а також через механізми залучення адвокатів та інших юристів до надання юридичних послуг. Сьогодні чимало проблем залишається у правників, які надають безоплатну правову допомогу в кримінальних провадженнях, пов'язаних із ідентифікацією суб'єктів, які надають та отримують таку допомогу, визначення її змісту та фінансування, а також реалізація права на безоплатну правову допомогу особами, засудженими до позбавлення волі.

(C) О.В. Крушніцька, 2020

* Oksana Krushnitska, Postgraduate student of Yuriy Fedkovych Chernivtsi National University 
Аналіз останніх досліджень і публікацій. Значну увагу проблемам надання безоплатної правової допомоги займалися такі науковці: Т.В. Варфоломєєва, Т.Б. Вільчик, Г.П. Власова, І.Ю. Головацький, В.Г. Гончаренко, В.Т. Маляренко, М.М. Михеєнко, С.В. Оверчук та ін.

Формулювання мети статті. Дослідити окремі проблеми надання безоплатної правової допомоги у кримінальному провадженні.

Виклад основного матеріалу. Правові основи надання безоплатної правової допомоги адвокатами закріплені у ст. 59 Конституції України, згідно з якою кожен має право на професійну правничу допомогу. У випадках, передбачених законодавством, ця допомога надається безкоштовно. Кожен вільний у виборі захисника своїх прав ${ }^{1}$.

Як зазначає I.В. Хондогій, юридична допомога є основою для здійснення інших прав, включаючи право на справедливий судовий розгляд, необхідні умови для здійснення цих прав, і важлива гарантія, що забезпечує фундаментальну справедливість процесу кримінального судочинства та довіру громадськості до нього 2 .

Тому головною передумовою забезпечення права особи на правову допомогу можна вважати створення надійних правових та організаційних підстав для її фактичного надання. Для виконання завдань, викладених у Концепції формування системи безоплатної правової допомоги в Україні від 9 червня 2006 р. ${ }^{3}$, а саме: 1) створення взаємопов'язаних компонентів системи - первинна та вторинна правова допомога; 2) забезпечення належного рівня та оптимального порядку виплати правової допомоги за рахунок коштів державного бюджету; 3) встановлення чітких критеріїв доступу осіб до безоплатної правової допомоги; 4) створення ефективної моделі управління системою безоплатної правової допомоги та ії фінансування, прийнято Закон України «Про безоплатну правову допомогу» ${ }^{4}$, який визначав зміст права на безоплатну правову допомогу, порядок здійснення цього права, підстави та порядок надання безоплатної правової допомоги, реалізація даного права, державні гарантії надання безоплатної правової допомоги.

Виходячи $з$ положень Закону України «Про безоплатну правову допомогу», правова допомога у кримінальному провадженні належить до безоплатної вторинної правової допомоги, яку частиною першою ст. 13 цього Закону визначено як певну державну гарантію, яка полягає у створенні рівних можливостей доступу осіб до правосуддя 5 .

Вона включає такі види юридичних послуг: 1) захист; 2) представництво інтересів осіб, які мають право на безоплатну вторинну правову допомогу в судах, інших державних органах, органах місцевого самоврядування, перед іншими особами; 3) складання процесуальних документів 6 .

Безпосередньо та виключно у сфері кримінального провадження $є$ правова допомога, визначена пунктом першим частиною першою ст. 14 Закону України «Про безоплатну правову допомогу» визначено категорії громадян, які мають право на безоплатну вторинну правову допомогу. Для визначення суті такої правової допомоги необхідно звернутися до понять «обвинувачення» та «захист». Відповідно до П. 13 ст. 3 КПК України обвинувачення - це твердження, що особа вчинила діяння, передбачене Законом України про кримінальну відповідальність, вчинене в порядку, встановленому цим Кодексом. Таким чином пункт третій ст. 3 КПК України підкреслюється поняття «державне обвинувачення» у значенні процесуальної діяльності прокурора, яке полягає в притягненні до відповідальності обвинувачення з метою забезпечення кримінальної відповідальності особи, яка вчинила кримінальне правопорушення7. Визначаючи тип вторинної правової допомоги, що надається безкоштовно, законодавець говорить про «захист від обвинувачення», тобто таку допомогу слід розуміти значною мірою, застосовуючись як на досудовій, так і на судовій стадії кримінального провадження та включаючи спростування звинувачень обвинувачення як прокурором, так і іншими суб'єктами, яким надано таке право, включаючи органи досудового розслідування та потерпілих.

Важливо підкреслити, що у сфері кримінального провадження правову допомогу можуть надавати лише адвокати. Виходячи з положень частини другої ст. 45 КПК України, адвокат не може бути адвокатом, інформація якого не внесена до Єдиного реєстру адвокатів України або щодо якого Єдиний реєстр адвокатів України містить інформацію про припинення або зупинення права на здійснення адвокатської діяльності. Тому предмет юридичної допомоги у кримінальному провадженні чітко визначений. У своєму рішенні законодавець «зрівняв» можливості підозрюваного, обвинуваченого та потерпілого отримати правову допомогу, надавши потерпілому представнику адвоката додаткові можливості впливати на хід судового розгляду та результати його розгляду, захист їх прав та законних інтересів.

Важливою частиною розглянутого питання є ідентифікація осіб, яким необхідно отримати безоплатну вторинну правову допомогу у кримінальному провадженні.

Міжнародні стандарти в цій галузі проголошують, що уряди повинні надавати достатньо фінансових ресурсів для надання юридичних послуг бідним, а також іншим неблагополучним особам. У всіх випадках, коли цього вимагають інтереси правосуддя, кожна така особа має право на допомогу адвоката, досвід та компетенція якого відповідають природі правопорушення, та який призначається безкоштовно для надання ефективної правової допомоги, якщо особі бракує достатніх коштів для оплати послуг адвоката ${ }^{8}$.

Судова практика Європейського суду з прав людини зазначає, що потреба в правовій допомозі в інтересах правосуддя повинна визначатися, зокрема, виходячи з:

1) тяжкості обвинувачення та суворості можливого вироку;

2) складності юридичних та фактичних обставин справи;

3) важких життєвих обставин, в яких опинилася людина.

Можна припустити, що дані критерії були відображені у ст. 14 Закону України «Про безоплатну правову допомогу», який визначив суб'єктів права на отримання безоплатної вторинної правової допомоги. Водночас аналіз цих суб'єктів дає змогу розділити їх на загальні та спеціальні. 
Загальними суб’єктами права на безоплатну вторинну правову допомогу можуть вважатися особи, які проживають під юрисдикцією України, якщо середньомісячний загальний дохід їх сім’ї нижчий за прожитковий мінімум, обчислений та затверджений відповідно до Закону України «Про прожитковий мінімум», для осіб, що належать до основних соціальних та демографічних груп, осіб з обмеженими можливостями, які отримують пенсію або допомогу замість пенсії, менше двох прожиткових мінімумів для інвалідів. У цьому випадку право на всі види юридичних послуг, що входять до безоплатної вторинної правової допомоги, пов'язане з бідністю особи, їі фінансовим станом.

Інші категорії таких суб' єктів є особливими, i їх розмежування пов'язане з суб'єктивними (пов'язаними 3 особливостями правового статусу особи) або об'єктивними (пов'язаними з життєвими обставинами, в яких опиняється особа) чинниками 9 .

Ряд визначених у ст. 14 Закону України «Про безоплатну правову допомогу» об'єктивних чинників надання особі права на безоплатну вторинну правову допомогу пов'язані зі сферою кримінального провадження. Так, на це мають право такі особи: заарештовані за підозрою у вчиненні злочину; кому було обрано тримання під вартою як запобіжний захід; особи у кримінальному провадженні, стосовно яких відповідно до положень КПК України адвоката залучає слідчий, прокурор, слідчий суддя чи суд для здійснення захисту за призначенням або проведення окремої процесуальної дії. Ці особи мають право на захист від обвинувачення.

Примітно, що Закон України «Про безоплатну правову допомогу»10 та КПК України мають взаємні посилання на один одного (ст. 52 КПК) ${ }^{11}$.

Далі хотілося б розглянути проблемні питання реалізації права на безоплатну правову допомогу засуджених. У сучасній реальності ситуація із забезпеченням такого права для засуджених в Україні здається набагато менш оптимістичною. I причини цього - такі фактори.

По-перше, у багатьох випадках для отримання безоплатної вторинної правової допомоги необхідно зібрати необхідні документи, що підтверджують належність особи до певної категорії суб’ єктів, що підпадають під дію закону. Тобто засуджений повинен документально підтвердити, що його засудили в Україні за злочин, що його покарання набрало чинності, що його засуджено до таких покарань, як ув'язнення або тримання під вартою в дисциплінарному батальйоні військовослужбовців або обмеження волі. Недостатньо надати копію вироку для підтвердження статусу засудженої особи, оскільки документи до центрів забезпечення безоплатної правової допомоги мають бути подані в оригіналі або в належним чином завіреній копії. Але чи легко зробити копію документа в приміщенні пенітенціарної служби, чи легко отримати належну довідку від керівника пенітенціарної служби (особливо у випадках, коли засуджений порушує режим або коли адміністрація пенітенціарної служби порушує режим прав і свобод людини і не хоче публічності)? Питання, на наш погляд, риторичне.

Якщо особа не має підстав для отримання вторинної правової допомоги (не в змозі підтвердити свій статус суб'єкта права), Центр отримання вторинної правової допомоги приймає рішення про відмову у наданні вторинної правової допомоги та направляє копія цього рішення особі, яка звернулася 3 проханням про надання такої допомоги, роз'яснюючи порядок оскарження рішення про відмову в наданні безоплатної вторинної правової допомоги ${ }^{12}$.

По-друге, режим ув'язнення засудженого в установі виконання покарань передбачає низку обмежень щодо здійснення конституційних прав особи, зокрема - і право на повагу до приватного та сімейного життя, в тому числі - секретності листування.

Так, у Кримінально-виконавчому кодексі України зазначається: «Засудженим військовослужбовцям дозволяється надсилати та отримувати листи та телеграми без обмеження їх кількості. Вручення вхідних листів здійснює представник дисциплінарного батальйону, у присутності якого засуджений має їх розпечатати. Вміст листів не підлягає перегляду».

Таким чином, відправлення засудженими листів до центрів надання безоплатної правової допомоги, із запитом про забезпечення права на безоплатну правову допомогу, та отримання відповідей на такі листи, не є проблемою для засуджених військовослужбовців.

Ситуація з реалізацією права на безоплатну правову допомогу особами, засудженими до позбавлення волі, є зовсім іншою.

Так, з одного боку, частина перша ст. 107 Кримінально-виконавчого кодексу України серед прав та обов'язків засуджених до позбавлення волі містить право «листуватися з особами поза колоніями, здійснювати телефонні розмови 3 ними, у тому числі в мережі мобільного зв'язку, використовувати Інтернет»13.

Але вже в ст. 113 того ж джерела закону можна зустрітися із механізмом регулювання особами, засудженими до позбавлення волі, їхнім правом на листування: «Засудженим дозволяється одержувати і відправляти листи і телеграми за свій рахунок без обмеження їх кількості. Листування між перебуваючими в місцях позбавлення волі засудженими, які не є родичами, допускається тільки 3 дозволу адміністрації колонії. Кореспонденція, яку одержують і надсилають засуджені до відбування покарання у виправних колоніях мінімального рівня безпеки із загальними умовами тримання, середнього та максимального рівня безпеки, підлягає перегляду. Кореспонденція, яку засуджені адресують Уповноваженому Верховної Ради України з прав людини, Європейському суду з прав людини, а також іншим відповідним органам міжнародних організацій, членом або учасником яких є Україна, уповноваженим особам таких міжнародних організацій, до суду та прокуророві, перегляду не підлягає і надсилається за адресою протягом доби з часу ії подачі. Кореспонденція, яку засуджені одержують від зазначених органів та осіб, перегляду не підлягає. Кореспонденція, яку засуджені адресують захиснику у кримінальному провадженні, що здійснює свої повноваження відповідно до Кримінального процесуального кодексу України, перегляду не підлягає й надсилається за адресою протя- 
гом доби з часу їі подачі. Кореспонденція, яку засуджені одержують від такого захисника, перегляду не підлягає. Засуджений має право передати кореспонденцію захиснику в кримінальному провадженні, що здійснює свої повноваження відповідно до Кримінального процесуального кодексу України, безпосередньо під час побачення з ним.

Висновки. Отже, головною передумовою забезпечення права особи на правову допомогу можна вважати створення надійних правових та організаційних підстав для іiі фактичного надання.

Листування ув'язненого, засудженого до позбавлення волі, з центрами безоплатної правничої допомоги, по-перше, підлягає перегляду адміністрацією пенітенціарної установи, по-друге, такі листи взагалі не обов'язково надсилатимуться в цілому, по-третє, якщо такі листи надсилаються, де це можливо, то законодавством не встановлено строків для їх надсилання. Отже, право на своєчасне та ефективне отримання безоплатної правової допомоги ув'язненими до позбавлення волі може бути порушено. Альтернативно, право на амністію, право на помилування та право на перегляд судового рішення за нововиявленими або виключними обставинами та інші права та свободи, які не обов’язково стосуються надання особі доступу до правосуддя, можуть бути порушені або недоступні засудженій особі.

${ }_{1}^{1}$ Конституція України: Закон від 28 червня 1996 р. № 254к/96-BP. URL: https://zakon.rada.gov.ua/laws/show/254к/96-вр

2 Хондогій І.В. Система безоплатної правової допомоги як реалізація конституційного права громадян України на професійну правничу. Актуальні проблеми правознавства. 2017. Вип. 2. С. 138-146. С. 138.

3 Концепції формування системи безоплатної правової допомоги в Україні: Указ Президента України; Концепція від 09 червня 2006 р. № 509/2006. URL: https://zakon.rada.gov.ua/laws/show/509/2006

4 Про безоплатну правову допомогу: Закон України від 02 червня 2011 p. № 3460-VI. URL: https://zakon.rada.gov.ua/laws/ show $/ 3460-17$

5 Там само.

6 Русанова І.О. Деякі проблеми надання адвокатами безоплатної правової допомоги у кримінальному провадженні. Юрист Украӥни. 2013. № 3. С. 69-74. С. 69. URL: http://nbuv.gov.ua/UJRN/uy_2013_3_13

7 Кримінальний процесуальний кодекс України: Кодекс України; Закон, Кодекс від 13 квітня 2012 p. № 4651-VI. URL: https://zakon.rada.gov.ua/laws/show/4651-17

8 Яновська О.Г. Європейські стандарти надання безоплатної правової допомоги в кримінальному судочинстві: проблеми реалізації в Україні. Науковий вісник Міжнародного гуманітарного університету. Юриспруденція. 2013. Вип. 6-1(2). С. $199-202$. C. 199.

9 Там само. С. 201

10 Про безоплатну правову допомогу: Закон України від 02 червня 2011 р. № 3460-VI. URL: https://zakon.rada.gov.ua/laws/ show/3460-17

11 Кримінальний процесуальний кодекс України: Кодекс України; Закон, Кодекс від 13 квітня 2012 р. № 4651-VI. URL: https://zakon.rada.gov.ua/laws/show/4651-17

12 Кармазіна К.Ю., Гончарук Ю.О. Надання безоплатної правової допомоги засудженим особам в Україні. Правова держава. 2018. № 32. С. 66-77. С. 66.

13 Кримінально-виконавчий кодекс: Кодекс України; Закон, Кодекс від 11 липня 2003 p. № 1129-IV. URL: https://zakon. rada.gov.ua/laws/show/1129-15

\section{Резюме}

Круиніцька О.В. Окремі проблеми надання безоплатної правової допомоги у кримінальному провадженні.

В статті розглянуто окремі проблеми надання безоплатної правової допомоги у кримінальному провадженні.

Виявлено та показано, що головною передумовою забезпечення права особи на правову допомогу можна вважати створення надійних правових та організаційних підстав для іiї фактичного надання.

Доведено, що листування ув'язненого, засудженого до позбавлення волі, з центрами безоплатної правничої допомоги, по-перше, підлягає перегляду адміністрацією пенітенціарної установи, по-друге, такі листи взагалі не обов'язково надсилатимуться в цілому, по-третє, якщо такі листи надсилаються, де це можливо, то законодавством не встановлено строків для їх надсилання.

Окреслено деякі проблеми, зокрема право на своєчасне та ефективне отримання безоплатної правової допомоги ув'язненими до позбавлення волі може бути порушено. Альтернативно, право на амністію, право на помилування та право на перегляд судового рішення за нововиявленими або виключними обставинами та інші права та свободи, які не обов'язково стосуються надання особі доступу до правосуддя, можуть бути порушені або недоступні засудженій особі.

Ключові слова: правова допомога, безоплатна правова допомога, суб’єкт права, безоплатна вторинна допомога, кримінальне провадження.

\section{Резюме}

Крушницкая О.В. Отдельные проблемы предоставления бесплатной правовой помощи в уголовном производстве. В статье рассмотрены отдельные проблемы предоставления бесплатной правовой помощи в уголовном производстве.

Выявлено и показано, что главной предпосылкой обеспечения права человека на правовую помощь можно считать создание надежных правовых и организационных оснований для ее фактического предоставления.

Доказано, что переписка заключенного, осужденного к лишению свободы, с центрами бесплатной юридической помощи, во-первых, подлежит пересмотру администрацией пенитенциарного учреждения, во-вторых, такие письма вообще не обязательно отправлять в целом, в-третьих, если такие письма направляются, где это возможно, то законодательством не установлены сроки для их отправки.

Определены некоторые проблемы, в частности право на своевременное и эффективное получение бесплатной правовой помощи заключенными к лишению свободы может быть нарушено. Альтернативно, право на амнистию, право на помилование и право на пересмотр судебного решения по вновь открывшимся или исключительным обстоятельствам и другие права и сво- 
боды, которые не обязательно касаются предоставления лицу доступа к правосудию, могут быть нарушены или недоступны осужденному лицу.

Ключевые слова: правовая помощь, бесплатная правовая помощь, субъект права, бесплатная вторичная помощь, уголовное производство.

Summary

Oksana Krushnitska. Some Problems of Free Legal Aid in Criminal Proceedings.

The article deals with some problems of providing free legal aid in criminal proceedings.

It has been identified and shown that the main prerequisite for ensuring the right of a person to legal aid can be considered to be the creation of reliable legal and organizational grounds for its actual provision.

It is proved that the correspondence of a prisoner sentenced to imprisonment with the centers of free legal aid is, firstly, subject to review by the administration of the penitentiary institution, secondly, such letters will not necessarily be sent as a whole, and thirdly if such letters are sent wherever possible and there is no legal deadline for sending them.

Some issues are outlined, such as the right to receive legal aid in a timely and effective manner to prisoners in prison. Alternatively, the right to amnesty, the right to pardon, and the right to review a judgment in newly discovered or exceptional circumstances, and other rights and freedoms that are not necessarily related to giving a person access to justice may be violated or inaccessible to the sentenced person.

Therefore, the right to receive legal aid in a timely and effective manner to prisoners in prison may be violated. Alternatively, the right to amnesty, the right to pardon, and the right to review a judgment in newly discovered or exceptional circumstances, and other rights and freedoms that are not necessarily related to giving a person access to justice may be violated or inaccessible to the sentenced person.

Key words: legal aid, free legal aid, legal entity, free secondary aid, criminal proceedings.

DOI: 10.36695/2219-5521.1.2020.67

УДК 343.9 .01

\section{Д.0. ХОМИч}

Дмитро Олегович Хомич, аспірант Східноєвропейського національного університету імені Лесі Українки*

ORCID: 0000-0001-8446-2453

\section{ВИВЧЕННЯ ТА СИСТЕМАТИЗАЦІЯ СПОСОБІВ ВИКРАДЕНЬ ПРИРОДНОГО ГАЗУ ШЛЯХОМ ВТРУЧАННЯ В РОБОТУ ПРИЛАДУ ОБЛІКУ}

Постановка проблеми. Сьогодні природний газ є стратегічно вирішальною сировиною для України та впливає на нашу державну незалежність. Тому налагодження результативного контролю за його доцільним використанням та виявлення випадків несанкціонованого користування й фактів крадіжки газу - базис економічної стабільності в цілому держави.

Криміналістика у своєму становленні та розвитку пройшла декілька етапів: від описового, де здійснювалось прояв закономірностей навколишньої реальності, до аналітичного й логічного дослідження, завдяки чому стало можливим створення криміналістичних наукових теорій та понять. Саме таким науковим поняттям $€$ спосіб вчинення злочину, котрий входить до криміналістичного вчення про спосіб вчинення злочину.

Спосіб вчинення крадіжки є основним елементом криміналістичної характеристики, адже поєднує одним замислом систему дій стосовно приготування, вчинення та приховання злочину.

Вивчаючи питання кримінологічної характеристики злочинів, які відбуваються у сфері газопостачання, не можна залишити без уваги вивчення питань, пов'язаних із способом вчинення злочину та особою злочинця.

Аналіз останніх досліджень і публікацій. Дослідженням проблем криміналістичної характеристики злочинів займалися різні науковці, зокрема: В.П. Бахін, І.Г. Богатирьов, А.М. Бойко, І.А. Возгрін, В.К. Гавло, І.Ф. Герасимов, В.В. Голіна, В.Г. Гончаренко, Г.В. Дідківська, О.М. Джужа, Л.Я. Драпкін, А.Ф. Зелінський, О.Н. Колесниченко, В.О. Коновалова, Г.А. Кушнір, В.Л. Підпалий, Н.А. Сенчик, В.В. Сташис, В.Я. Тацій, П.Л. Фріс, та ін.

На переконання А.Ф. Зелінського, особа злочинця це альфа і омега кримінальної психології. Людина, яка порушила закон та $€$ автором злочину перетворюється з громадянина на злочинця, який відхиляється суспільною свідомістю1. У злочинців під час вчинення злочину виробляються специфічні вміння, навички та нахили. Вчинення злочинів певним способом $€$ передумовою злочинної професіоналізації. Знання специфіки способів професійної злочинної діяльності виступає ключем до виявлення винних.

Як визнає В.О. Коновалова, про особу злочинця слід говорити в тому випадку, коли йдеться про певний порядок злочинних дій. Це зумовлено тим, що особистість формується в процесі діяльності (у тому числі і злочинної). Вчинення злочинних дій відображається на психологічній структурі особистості, виникненні в неї антигромадської спрямованості².

(С) Д.О. Хомич, 2020

* Dmitro Homich, Postgraduate student of Lesya Ukrainka Eastern European National University 